\title{
Research Paper: Designing a Model to Develop Businesses for the Cluster Processing of Garden Products in Kermanshah Province and its Relationship with Rural Development
}

\author{
Hossein Heidari ${ }^{* *}$, Abdolhamid Papzan², Alireza Darban Astane ${ }^{3}$
}

1. Ph. D. Student Agricultural Development, Department of Agricultural Extension and Education, College of Agriculture, Razi University, Kermanshah, Iran.

2. Associate Professor, Department of Agricultural Extension and Education, College of Agriculture, Razi University, Kermanshah, Iran.

3. Assistant Professor, Department of Geography and Rural Planning, College Geography, Tehran University, Iran.

\begin{tabular}{|c|c|}
\hline $\begin{array}{l}\text { Use your device to scan } \\
\text { and read the article online }\end{array}$ & Citation: Heidari, H., Papzan, A., \& Darban Astane, A. (2018). Designing a Model to Develop Businesses for the Cluster \\
\hline 口Fra & Processing of Garden Products in Kermanshah Province and its Relationship with Rural Development. Journal of Sustainable \\
\hline & Rural Development, 2(1-2), 39-50. https://doi.org/10.32598/jsrd.01.03.240 \\
\hline arsis & del': https://doi.org/10.32598/jsrd.01.03.240 \\
\hline
\end{tabular}

\section{Article info:}

Received: 06 Jan. 2018

Accepted: 06 April 2018

\section{Keywords:}

Agricultural business, Agricultural cluster, Rural entrepreneurship, Rural employment, Garden crops

\section{ABSTRACT}

Purpose: The purpose of this study was to design a model to develop a series of businesses for the cluster processing of garden products in Kermanshah province and its relationship with rural development.

Methods: This study is based on a qualitative research design and the grounded theory method. The study population included the experts of the industrial town and the horticulture industry affiliated to the Agriculture Organization of Kermanshah province as well as cluster developers in the province. They were selected through purposeful sampling.

Results: A total of 83 concepts related to the research topic were extracted through open coding. These concepts were formulated in 23 subcategories that formed the conceptual basis for the cluster development of businesses in garden products. Geographic focus, trust, cooperation and competition, opportunities and challenges facing businesses as causal conditions, entrepreneurship and collective identity, access to appropriate infrastructures and markets, regional economic prosperity and access to appropriate technology, cluster development agents, startups, existence of boycott and climate change are the tenets, concepts, and phenomena that need the attention or support of the government and the institutions involved. Also, business synchronization, training of the workforce and effective provision of business services are considered as the interaction strategies for the cluster development of horticultural products in Kermanshah province. The outcome of such a state of affairs would be agricultural development, economic development, market development, human development and socio-cultural development.

Conclusion: Designing this native model can set an example to follow by rural development $\mathrm{p}$ lanners, industrial towns, the Agricultural Organization, the practitioners of the related businesses, and gardeners. 


\section{Introduction}

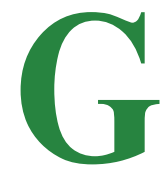

ardening is one of the important agricultural sectors in Iran. Its importance is due to the production of high-value food and foreign exchange. Producing more than 18 million tons of fruit, i.e. $230 \mathrm{~kg}$ per person, Iran ranks first in the Middle East and ranks ninth in the world (Moradi et al., 2015). The climate diversity, richness of soil and water, potential of land for the cultivation of horticultural products, steep slopes, and practicing the principles in the economics of gardening have made Kermanshah province one of the most prone areas for the production of horticultural products of various types (Moradi et al., 2015). According to the statistics of 2017, the garden products at fertile and non-fertile levels in the province included 234158 tons of apples, pears, cherries, apricots, plums, peaches, nectarines, grapes, berries and certain fruits to pick unripe (Ahmadi et al, 2016). In addition, paying attention to small-scale reformations and workshops in rural areas has been one of the livelihood strategies implemented. Many scholars agree on the impact of this strategy on rural employment and sustainable livelihood in rural areas (Sajasi Kheidari et al., 2013; Shakori, 2011; Motiei langrodi \& Najafi Kani, 2011; Kopahi \& Darban Astane, 2002). The significance of this strategy is so great that the Global Horticulture (Global Hurt) initiative has labeled it as a way to achieve the Millennium Development Goals (MDGs) (Aghasi zade et al., 2006). In this regard, one of the policies for the sustainable develop$\mathrm{m}$ ent of the agricultural sector is inter-agency cooperation, which has been at the forefront of the world's s cientific communities. Termed variably, inter-firm collaboration can take place in a variety of ways, one of which is clustering (Radfar, 2013). A cluster refers to as a set of business enterprises based in a particular geographic region, which operate in a single business, complement one another, and share challenges and opportunities (Mansori \& Aziz Mohamadlo, 2009). The presence of clusters creates many competitive advantages for business units through the cooperation and competition of the active businesses in the cluster, for which the required conditions and infrastructures are already provided (Jin et al., 2012; Papzan \& delangizan, 2008).

In Iran, clause 4, article 27, of the sixth development plan emphasizes the importance of business clusters and job creation in rural areas (Hiedari et al., 2017) To this end, various studies have been carried out on businesses and clusters in various industries. However, none of these studies have comprehensively examined the factors influencing the development of cluster processing of garden products. Clustering is essentially an endogenous development policy based on regional, social and economic conditions and structures. The pattern for the development of each cluster is unique, and it is not possible to suggest one pattern for all clusters. Therefore, the aim of this study is to provide a model for the clustering of garden products in Kermanshah province and to examine its interaction with the rural development process. To achieve this goal, the following questions are presented. What are the causal conditions for the development of clusters in horticulture? What are the principal factors for the development of such clusters? What are the interventional conditions in this case? What are the development strategies in this regard? What are the consequences of developing clusters in garden production?

\section{Literature Review}

Improvement, expansion, and industrialization of garden production as well as the development of business clusters in this field are a new issue in the Iranian agricultural sector. The issue has not been sponsored or directed yet, nor has much research been conducted on it. However, the bulk of research in this regard is considerable in other countries.

In their study, Musso \& Francioni (2015) showed that agro-food clusters that produced various types of beverages in the countryside are attracted by just a few tourists, and those active in clusters export their drinks to foreign and international markets. In another study Sharma \& Anupam (2014) suggested that cluster development can be an important tool for agricultural development, for farmers and for small and medium-sized businesses. The benefits can be gained through membership in agricultural clusters, increase of productivity by collaboration with agricultural businesses, access to information, synergies and public goods, and quick innovations by collaboration with research centers. In this regard, the results indicated that a cluster can be a national or regional brand and attract the factors affecting local and rural development. The results also showed that, to be developed, agricultural clusters need the support and cooperation of public and private institutions. As Sharif Z adegan and Noura'i (2015) suggested, development of clusters should be based on such physical characteristics as the geographical features of industries, labor division, the existence of specialized labor, technology, cluster support service providers, and infrastructures as well as operational features including economic links, technological links and institutional links that can create various economic benefits and new ideas. This is in line 
with the process of globalization to form and promote a bunch of social institutions and set up relationships among them in certain regions, thus providing a framework for strengthening social capital and promoting civil society. In another study by Izadi and Mosleh Shirazi (2012), it was found that cluster development can occur through the implementation of the Cluster Development Program which requires the application of new market a ccess policies, creation of suitable supply networks, distribution of networks for cluster sales, building trust, training, increasing the level of technology and using new devices. As a result of practicing these suggestions, an export approach has emerged in the Meymand cluster.

Hoffman et al. (2014) showed that relationships and c ooperation within clusters can lead to knowledge t ransfer among cluster business owners. Given that collaboration within cluster businesses and knowledge transfer among them is one of the factors influencing the development of clusters, it can be argued that transfer of knowledge among the clusters in a business leads to cluster development. In this regard, Roy and Thorat (2008) showed that factors such as the collaboration and interaction among all cluster members, the use of new knowledge through communication with agriculture research centers, government policies for providing lowinterest loans and marketing are influential in the success of cluster development.

A biola (2006) referred to some factors affecting the success of clusters. These factors were categorized under activities in the form of collective actions, such as c ollaboration between producers and support institutions, joint marketing, sharing knowledge with other producers, government support and business communication. Furthermore, working in the cluster with experts and universities was mentioned as an important factor for the success and development of clusters. In addition, the results gained in a case study by Kord \& Khashi (2014) showed that six components are involved in the formation and growth of clusters, including geographical concentration, environmental factors, infrastructure, strategy, structure, interconnection, and demand conditions. Among these, geographical concentration and interconnection were respectively the most and the least effective factors in creating an industrial cluster for the dates of Saravan region.

According to a study by Parausic et al. (2013), the development of clusters in Serbia required the creation of new agricultural businesses with a favorable work environment, small and medium-sized enterprises, enact- ment of predictable agricultural policies, entrepreneurial development projects aimed at joint activities, innovation in the processing and cooperation among the existing businesses.

A review of the literature reveals that cluster development is an important tool for the promotion of gardening products. Despite the importance of identifying and developing clusters in garden businesses, there is dearth of systematic and comprehensive research in this field in Iran. Clusters are essentially endogenous development models based on regional, social and economic conditions and structures. The development pattern of a cluster in a region is unique and cannot be used as a template for other clusters. On this basis, the aim of this research is to provide a model for the cluster processing of garden products in Kermanshah province and its relationship with rural development programs.

\section{Methodology}

The present study was carried out using a qualitative approach and the Grounded Theory method. The study population consisted of the key informants in the Industrial Town and the experts of the Agriculture Organization of Kermanshah province who were selected according to the nature of qualitative research in a targeted manner through theoretical sampling. In this research, in order to get acquainted with the key informants at the companies of the industrial town of Kermanshah province, they were interviewed, and then the cluster development experts were identified. The data were collected using semi-structured, individual and group interviews, direct observation and field notes. Using multiple methods in collecting the data in qualitative research increases the credibility of findings through the process, which is called triangulation (Cohen et al., 2000). After 12 semi-structured interviews with the experts (nine experts in the industrial town, two at the Agricultural Organization of Kermanshah province and one at a faculty of Razi University), each for at least an hour, theoretical saturation was achieved. The saturation came when the replies were repeated and no new concept was received from the interviewees. The collected data were analyzed $\mathrm{b}$ ased on the Strauss and Corbin recommendations in open, axial, and selective coding stages (Straus \& Corbin, 1998). Open coding involves the process of data review and conceptualization. In the present study, after the data were reviewed, some statements about cluster development were extracted and similar concepts were c oded with a common code. This stage ended with 83 concepts extracted. In the central coding, the links among the categories of the open source coding were 
discovered. Through the continuous comparison of the extracted concepts, the cluster development stage in the business of garden production was identified as a staggered paradigmatic model.

The paradigmatic model of the axial coding included c ausal conditions, phenomena, contexts, intervening c onditions, action/interaction strategies, and consequences (Heidari et al., 2015).

Casual conditions are the events that occur as general phenomena. Idea, or thought, is a pivotal phenomenon such as the development of gardening production business clusters. Context refers to the conditions of the occurrence of a phenomenon. It is difficult to diagnose the casual conditions or those values and situations in which certain variables occur or take effect. In any case, a phenomenon occurs or appears under certain conditions.

Intervening conditions facilitate or restrict strategies within a particular context. Strategies are cases that con- trol or spread a phenomenon. Also, consequences are the result of strategies. In the selective coding, relationships were formed between the other classes and the axis, and the cluster development model of gardening business was extracted. The main role of this stage of analysis is to create a storyline that includes all the classes.

\section{Findings}

The present research was designed to identify the factors affecting the research phenomenon, namely the development of clusters for gardening business in Ker$\mathrm{m}$ anshah province. The results of the analysis of the qualitative data indicated that the process of cluster development is based on open, central and selective coding stages. In the open-release process, after frequent reviews of the texts, 83 concepts were extracted, which were summed up through pivotal coding into $23 \mathrm{sub}$ classes. In the next step, each of these subclasses was distributed in the paradigm model according to its definition and attributes (Table 1).

Table 1. Concepts, subclasses and extracted classes

\begin{tabular}{|c|c|c|}
\hline Concepts & Subclasses & classes \\
\hline \multicolumn{3}{|l|}{ Trust among businesses } \\
\hline Trust of rural people in strangers & Trust & \\
\hline \multicolumn{3}{|l|}{$\begin{array}{l}\text { Trust of experts in government agencies such as Agriculture Bank and Agricul- } \\
\text { ture Jihad and their experts }\end{array}$} \\
\hline \multicolumn{3}{|l|}{ Horizontal communication (collaboration) among cluster-processing businesses } \\
\hline \multicolumn{3}{|l|}{$\begin{array}{l}\text { Vertical communication (collaboration) between cluster-processing businesses } \\
\text { and their predecessors }\end{array}$} \\
\hline $\begin{array}{l}\text { Business communication with private sector consultants in the field of process- } \\
\text { ing and sales }\end{array}$ & $\begin{array}{l}\text { Communication (coopera- } \\
\text { tion and competition) }\end{array}$ & \\
\hline Coordination and cooperation among relevant organizations & & $\begin{array}{l}\text { Casual circum- } \\
\text { stances }\end{array}$ \\
\hline \multicolumn{3}{|l|}{$\begin{array}{l}\text { The presence of businesses associated with gardening supplies (fertilizers, poi- } \\
\text { sons, tools, etc.) manufactures in the region }\end{array}$} \\
\hline \multicolumn{3}{|l|}{$\begin{array}{c}\text { The access of those who process the products to the primary suppliers of the } \\
\text { region }\end{array}$} \\
\hline \multicolumn{3}{|l|}{ Distance of stakeholders (producers) from one another } \\
\hline \multicolumn{3}{|l|}{ Existence of garden products processing in the region } \\
\hline \multicolumn{3}{|l|}{ Common challenges facing businesses } \\
\hline Opportunities shared by businesses & Common business future & \\
\hline
\end{tabular}

Source: Research findings 
Table 1. Concepts, subclasses and extracted classes

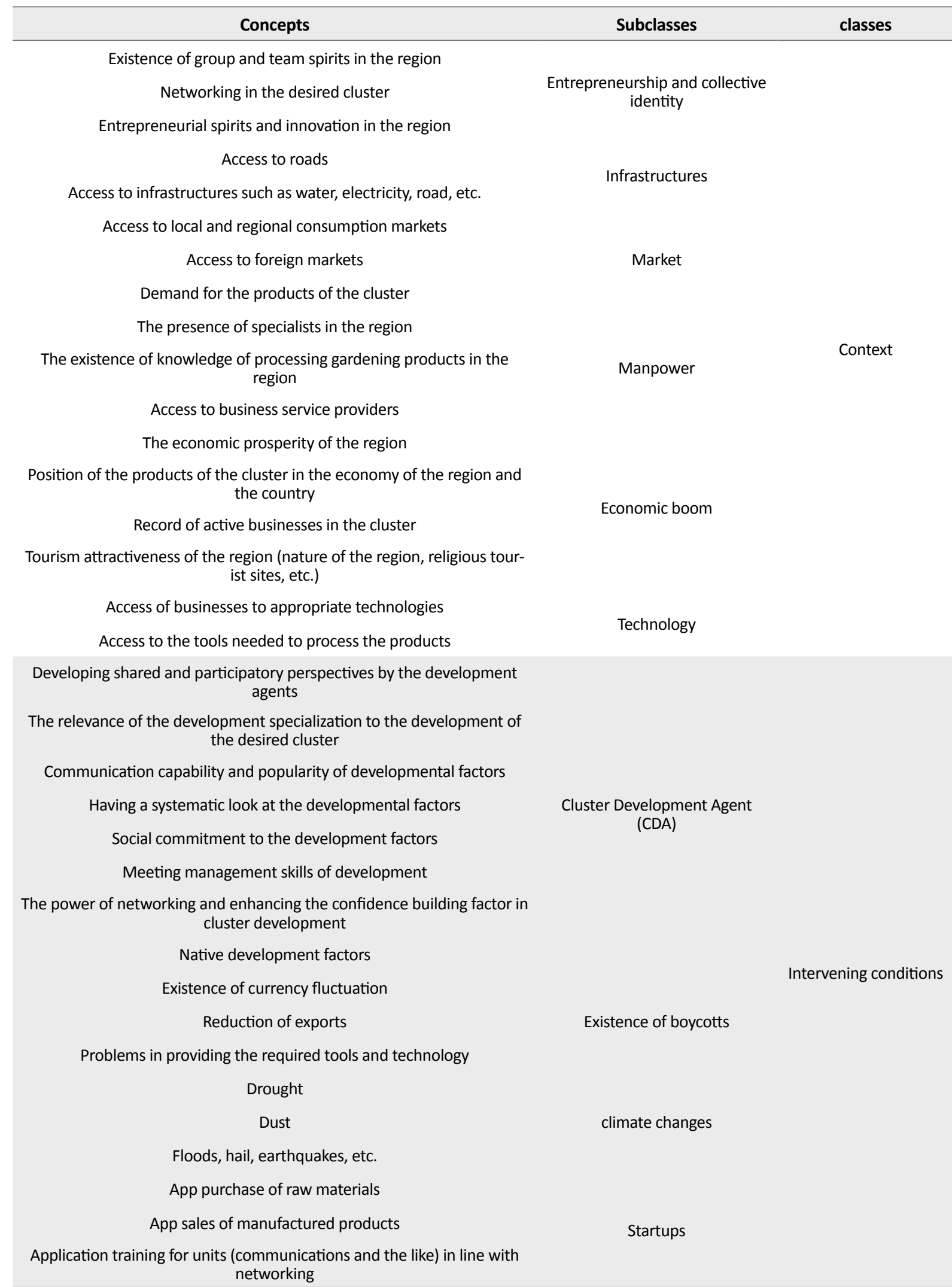

Source: Research findings 
Table 1. Concepts, subclasses and extracted classes

\begin{tabular}{|c|c|c|}
\hline Concepts & Subclasses & classes \\
\hline \multicolumn{3}{|l|}{ Legal support of units (clustering of agricultural businesses) } \\
\hline \multicolumn{3}{|l|}{$\begin{array}{l}\text { Cooperation of support organizations (Governor's office, Office of Indus- } \\
\text { tries and Mines, Agricultural Jihad, Regional Water Organization) }\end{array}$} \\
\hline \multicolumn{3}{|l|}{$\begin{array}{l}\text { Government support for attending exhibitions and supplying manufac- } \\
\text { tured products }\end{array}$} \\
\hline \multicolumn{3}{|l|}{ Facilitation of credit services to units } \\
\hline \multicolumn{3}{|l|}{ Pricing for manufactured products } \\
\hline \multicolumn{3}{|l|}{ Facilitation of attracting and investing jointly by units } \\
\hline \multicolumn{3}{|l|}{ Formation of a collective brand for cluster-based units } \\
\hline \multicolumn{3}{|l|}{ Providing transportation facilities for units } \\
\hline Organizing training for units through workshops and classes & & Strategies \\
\hline $\begin{array}{l}\text { Preparation and } \\
\text { distribution of publications and education extension for the units based } \\
\text { in the cluster on a regular basis }\end{array}$ & Workforce training & \\
\hline \multicolumn{3}{|l|}{ Providing advice on regular baccalaureate programs for units } \\
\hline \multicolumn{3}{|l|}{ Facilitation of the absorption and training of workforce through units } \\
\hline \multicolumn{3}{|l|}{ The availability of units to business service-providing companies } \\
\hline $\begin{array}{l}\text { The availability of units to quality raw materials } \\
\text { The availability of units to appropriate tools and technology }\end{array}$ & $\begin{array}{l}\text { Effective provision of services to } \\
\text { businesses }\end{array}$ & \\
\hline \multicolumn{3}{|l|}{$\begin{array}{l}\text { Providing communication-information services (via the Internet and the } \\
\text { internal network) }\end{array}$} \\
\hline \multicolumn{3}{|l|}{ Completion and development of agricultural value chains } \\
\hline \multicolumn{3}{|l|}{ Improving product quality } \\
\hline $\begin{array}{c}\text { Improving the level of production technology and mechanization in the } \\
\text { agricultural sector }\end{array}$ & Agricultural development & \\
\hline \multicolumn{3}{|l|}{$\begin{array}{l}\begin{array}{c}\text { Creating new job opportunities in the form of new businesses in the } \\
\text { region }\end{array}\end{array}$} \\
\hline \multicolumn{3}{|l|}{ Increasing the local income average } \\
\hline \multicolumn{3}{|l|}{ Reduction of production costs } \\
\hline \multicolumn{3}{|l|}{ Realization of economic scales in the agriculture sector } \\
\hline \multicolumn{3}{|l|}{ Attraction of funds in the agricultural sector } \\
\hline Improved marketing and product supply & & Consequences \\
\hline Increased export capacity & Market development & \\
\hline \multicolumn{3}{|l|}{ Raising communications and development of regional tourism } \\
\hline \multicolumn{3}{|l|}{ Development of creativity and entrepreneurship } \\
\hline Recruiting graduates and specialist workforce & Human development & \\
\hline \multicolumn{3}{|l|}{ Increasing the workforce knowledge } \\
\hline \multicolumn{3}{|l|}{ Increasing trust among businesses (networking) } \\
\hline Increasing work links & 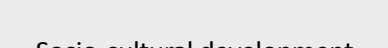 & \\
\hline Reducing villagers' migration & socio-cuitural development & \\
\hline
\end{tabular}

Source: Research findings 
After several revisions of the codes obtained in the open coding section and constant comparison by the researchers, the sub-categories of each paradigmatic model (i.e. casual circumstances, contexts, phenomena, intervening conditions, strategies, and consequences) were identified. In this way, the casual circumstances of four sub-categories (i.e. trust, geographic focus, common opportunities and common challenges and cooperation and competition among businesses) along with 14 codes were extracted for the class. For sub-contexts, there were six sub-categories (i.e. entrepreneurship and collective identity, access to infrastructures, market access, human resource access, regional economic prosperity and access to technology) were extracted along with 18 codes, For the category of the intervening conditions, four sub-categories (i.e. cluster expansion factor, sanctions, climate change and startups) were extracted along with 17 codes. For the strategy category, there were four sub-categories (i.e. government support and support of institutions, business synchronization, labor training, and effective service provision to businesses) were extracted along with 16 codes. Finally, for the consequences category, five sub-categories (i.e. agricultural development, regional economic development, market development, human development and socio-cultural development) were derived along with 18 codes. Also the research phenomenon was set to be the development of cluster processing for garden products. The paradigm of the research is presented in Figure 1.

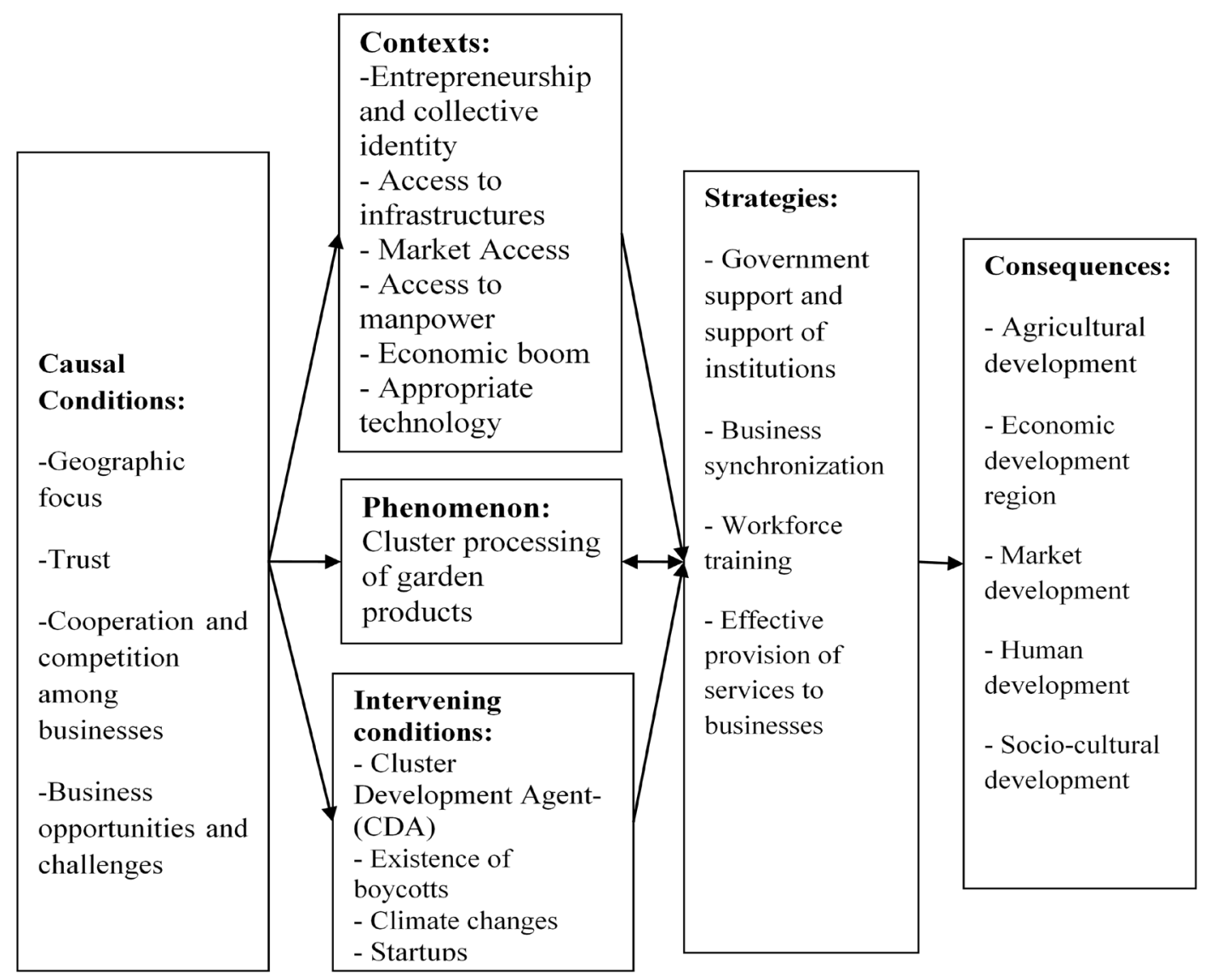

Figure 1. Model for the cluster processing of garden products in Kermanshah province 
4.1. Casual conditions related to the phenomenon of cluster development for the processing of garden products

Regarding geographical concentration, one of the interviewees stated that "with the access of people who process garden products to the materials and basic products needed in the region, reduction of costs, including the costs of transportation and raw materials, can make the cooperation of businesses possible". In the case of trust among businesses, the experts emphasized that one of the most important factors influencing the development of clusters is the trust of business owners in one another, in government agencies and in strangers. This facilitates the attraction of people and the investment of immigrants in rural areas. In this case, an interviewee stated that "in order to develop a cluster, there must be confidence among the businesses so that they can work jointly in, for example, purchasing raw materials or using tools." Most of the informants in this study pointed to horizontal and vertical cooperation among businesses as another important factor in cluster development. In this regard, the shared opportunities and challenges of businesses were referred to as a condition for cluster development. Also, it was pointed out that, if businesses have common opportunities and challenges, they can benefit from one another when facing the challenges ahead.

4.2. The context of the phenomenon of cluster development for processing garden products

The study participants stated that the spirit of entrepreneurship and workgroup creates new businesses for better market penetration, which, in turn, leads to cluster development. One of the experts said that "in order to succeed in clustering, one has to make networks among businesses so that they can collaborate; for example, a product sales network or shopping network for raw materials". A raw materials purchase network reduces the cost of purchasing for the businesses involved. In this regard, a product sales network can increase the bargaining power of businesses. The informants also said that, by getting access to appropriate infrastructures, costs can be reduced and launching the required businesses will be easy. Access to markets is also another underlying factor. In this case, an interviewee stated that "as long as products are exported to foreign markets and the marketing situation is appropriate, there is a high possibility of developing clusters for those products".

The informants also acknowledged that, if there is a specialized human resource with the knowledge of the processing in the region, the development of clusters will increase. One of them acknowledged that "the more the economy of the region booms, the easier the cluster development will be". Another one pointed out that "raising garden products is considered as a major strategy in the economy of the region and the country, and the possibility of developing a cluster will be enhanced if the government and supporting organizations vigorously support the intended cluster".

\subsection{Strategies of cluster development for the pro- cessing of garden products}

The participants in the research indicated that, in Iran, attention is paid more to clusters in other fields than agriculture (e.g. industry, and tourism) Therefore, the government and the companies in industrial towns should be particularly interested in the identification and development of agricultural and horticultural clusters. In this regard, according to the interviews, the most important subclasses of the government support include legal support of units (as in the clustering of agricultural businesses), facilitating credit services to units, supporting the attendance in exhibitions, supplying products, and cooperating with support organizations (e.g. the governor's office, Office of Industries and Mines, Agriculture Organization, and Regional Water Organization).

Also, the results indicated that the subcategory of business synchronization includes proper pricing for manufactured products, facilitating joint ventures by units, forming a collective brand for cluster-based units, and providing transportation facilities for units. In this respect, a participant stated that "the formation of a collective brand for the sale of products and the pricing of products are carried out alike; both lead to more sales and products and attraction of tourists to the region".

According to the study participants, workforce training is another sub-category. The measures to take in this case include training through workshops and classes for units, preparing and distributing magazines, extending education for cluster-based units, giving expert advice to units, and facilitating the recruitment and training of workforce through the unit codes of this subcategory. The study participants said that training the cluster stakeholders would lead to cluster development, income growth, creation of new businesses, and job creation. Another strategy in this sub-category is the effective provision of services to business units that have codes for an access to business service providers, quality raw materials, and communication-information services via the Internet and internal networks. The interviewees pointed out that, in order to develop a cluster, units should be provided with informa- 
tion in a variety of ways, such as the Internet, and have access to quality raw materials. Also, the active units in a cluster should be able to benefit from private sector business service providers. Therefore, the strategies of cluster development for processing garden products include government support, business synchronization, education and training, and giving effective services to business units. These factors together can facilitate the development of clusters. Once a cluster is made, it is found easy to put those factors to practice in that cluster.

\subsection{Intervening conditions affecting the strategies}

The research informants believed that development agents play important roles in cluster development. An agent must have the ability to communicate, have a holistic look at the system, create a common outlook for the program, and, after the development of a cluster, determine how much profit or income is to be obtained. The agent is also responsible for backing up the organization by attract enough participation in the business. In this regard, an interviewee stated that "with the intervention of the cluster development agent or a specialist in the field of agricultural products and rural development for about three years, the activities of the businesses in the network can be expanded, capital and government support can be attracted, and trust building occurs for cluster stakeholders. Once all these have been done, the intervening agents can slowly move away from the cluster."

The informants argued that the existence of boycotts due to foreign exchange fluctuations, decline of exports, and the difficulty in providing the required tools and technology has posed obstacles to the development of businesses. Also, climate change coded as the presence droughts, waterfalls, floods, hail, and the like has caused a reduction in the olive production and the quality of manufactured products.

In this respect, another sub-category that the experts emphasized is startups that can use apps to buy raw materials, sell products or even train and network units.

\subsection{Results of the development of clusters}

The participants in the study stated that training the units and government support would result in the completion of the agricultural value chain, the improvement of product quality and, ultimately, the development of agriculture and gardening. For instance, a participant stated that "the identification and development of clusters to process garden products will reduce the production costs and increase the income of the exploiters".
Another one said that "branding cluster products and coordinating businesses to carry out their activities can lead to the achievement of the scale economy and attraction of investment in agriculture."

Researchers have argued that branding, increasing product quality and using required technologies will lead to better marketability, improved marketing, increased exports, and ultimately, developed tourism in the region. Also, experts have said that paving the way for creativity, entrepreneurship, recruitment of university graduates and specialized workforce, and increase of the vocational knowledge of the workforce can lead to human development in the region.

Finally, socio-cultural development is another subcategory coming into being as a result of cluster development of garden products. In the interviews, the informants referred to codes, increased trust among businesses, increased job links, reduced rural immigration, and increased exchange of information among units. One of the interviewees, for example, stated that "by training the workforce and stakeholders, entrepreneurship and employment in the region rise, which will reduce the migration of the rural to cities".

\section{Discussion}

Agricultural cluster is an aggregate of agricultural producers and institutions that are active in the production of a particular product and have shared challenges and opportunities to add value to the product in question. A review of the cluster development experience in Iran shows that, in some cases, these activities have failed to maintain sustainability due to the lack of a comprehensive native model based on cooperation and practical experience in the field. In Iran, programs for the development of clusters have only continued for a while after the completion of projects. In addition, so far, no comprehensive research has been done to design a native model for the development of clusters in garden products business in Kermanshah province. Therefore, it is necessary to provide a clear and logical model for understanding and analyzing garden issues and the related processing industries. Managers and planners are supposed to take targeted and effective actions in relation to these businesses. It will help gardeners and landowners as well as those in processing industries to improve their performance and enhance their yield.

The development of business clusters for garden products processing in Kermanshah province has been studied in depth through the present qualitative research. 
This study and some others in the literature show that, in order to develop clusters, several factors have to be taken into account. They include a) entrepreneurship and collective identity, which lead to the creation of new businesses and the completion of a value chain for products, b) access to infrastructures (e.g. roads, water, electricity, telephone, and research center), which make it easier for consumers to access and connect with research centers, c) access to markets (domestic and foreign), which leads to the sale of products and increased incentives and production for operators, d) access to human resources through specialized workforce, which leads to the cultivation of horticultural products, and e) economic prosperity and access of businesses to technology and machinery, which provides a suitable basis for the improvement of garden products processing in the region. This result is consistent with the findings of Parausic et al. (2013), Zohorian \& Rahimnia (2015), Sharifzadegan \& Noraei (2015), Kord \& Khashi (2014), and Izadi \& Mosleh Shirazi (2012). In addition, the underlying conditions that cluster experts have identified for clustering horticultural products include geographic focus, business confidence, cooperation, and competition among businesses, shared opportunities and challenges, and joint ventures among businesses. This result is consistent with the findings of Parausic et al. (2013), Roy \& Thorat (2008), Hoffmann et al. (2014), Izadi \& Mosleh Shirazi (2012), Sharifzadegan \& Noraei (2015), and Kord \& khashi (2014). Geographic focus of businesses can reduce the cost of knowledge transfer and increase the use of equipment by stakeholders. Also, trust and communication along with other factors mentioned above are the most important conditions for the development of clusters in processing garden products. Indeed, if these conditions are embodied, cluster development will be easier. Cluster development, as a phenomenon in garden products businesses, has been positioned at the center of the model for processing garden products in Kermanshah province. Government support and the support granted by organizations are one of the important factors for cluster development as a strategy (Abiola, 2006; Sharma \& Anupam, 2014; Roy \& Thorat, 2008; Sharifzadegan \& Noraei, 2015; Zohorian \& Rahimnia, 2015). This result is consistent with the findings of Zohorian \& Rahimnia (2015). Therefore, cluster development agents should have communicative competence, expertise and commitment. They are also supposed to have a systematic and holistic look on and shared perspectives of cluster development programs.
It has emerged that cluster development programs have positive impacts on rural development and the reduction of the costs of gardening and cultivation by creating various networks. This includes the costs of raw materials and sales networks, and production. Besides, the bargaining power of manufacturers rises when selling their products. The identification and development of clusters for garden products promotes gardening processes and profits, attracts tourists and investors to rural areas, strengthens social assets, and creates new jobs in those areas. These factors lead to the development of rural economy. This is the result obtained by various researchers in different places, such as Musso \& Francioni (2015) in Italy, Sharma \& Anupam (2014) in India, and Sharifzadegan \& Noraei (2015) in Iran. In accordance with the results of this study and the propositions discussed herein, the following suggestions are made for future research:

\section{suggestions}

- According to the results, in order to develop clusters for garden products processing, those involved in the task are suggested to have a geographical focus on the production, create trust among businesses, focus on teamwork and networking, and promote group activities among businesses.

- In order to develop clusters for desired garden products, it is suggested that markets encompass the products so that the products can invariably be connected to the markets. There is also manpower in the area that is ready to participate in the work. It is suggested to be appropriately trained.

- Considering that cluster development plays an important role in attracting and government support and building trust and cooperation among businesses, it is suggested that appropriate agents be selected for the task of cluster development to process rural products in general and horticultural products in specific. Those agents are supposed to have the power of networking and increasing trust among villagers, communicative ability, systemic and holistic look, shared and participatory perspectives of programs, and local expertise in the field of rural development and agriculture.

- Considering the emphasis on various development programs in Iran and the clustering of rural businesses as a strategy according to the results obtained by the government and supporting institutions, it is suggested that the government, supporting institutions, and the corresponding organizations take more serious measures to 
cluster agricultural and gardening products in villages and support them like their support for industrial products.

- For future research, it is also possible to cluster other rural products, such as crops and livestock in rural areas, examine native model for the identification and development of the businesses in these fields, and design and implement a global model for rural environments.

\section{Acknowledgment}

The researchers thank the authorities of the industrial town in Kermanshah Province for sponsoring this research.

\section{Conflict of Interest}

The authors declared no conflict of interests.

\section{References}

Abiola, B. (2006). Knowledge, Technology and Growth: The Case Study of Wine Cluster in South Africa. WBI Africa Cluster Case Study. World Bank Institute, World Bank, Washington, D.C.

Aghassi Zadeh, F., Dashti, S. \& Etemadzadeh, A. H. (2006). Conceptual and Content Model of the Five-Year Plans of the Islamic Republic of Iran with an emphasis on the themes of the agricultural sector (1368-1388). Publication of the Economics Program, No. 300, pp. 15-21.

Ahmadi, K. gholizadhemati, F. Abdshah, H. Rezaei, M, M. Kazemifard, R \& Fazli, M. (2016). The statistics of garden products, Tehran, Ministry of Jihad-e-Agriculture, Deputy of Planning and Economic, Center Technology Information and Communication, First Edition : pp. 1-147.

Cohen, L. Manion, L., \& Morrison, K. (2000). Research Methods in education. First edition, Rutledge flamer publication.

Hiedari H, Papzan, A.H. Darbaneastane, A. (2017). Analysis of the status of agricultural business clusters and their development in Iran, Entrepreneurship in Agriculture, Vol. 5, No. 2. Pp 125-140.

Hiedari, H, Zarafshani, K \& Moradi, Kh. (2015). Qualitative Model of Social Capital Action with Rural Development Process Case: Farsinag rural in Kermanshah Province, Journal of Quarterly Space and Rural Development, Vol. 4, No. 1, Successive 11, pp. 131-146.

Hoffmann, V, Lopes, G, and Medeiros, J. (2014). “Knowledge transfer among the small businesses of a Brazilian cluster", Journal of Business Research, 67(5), 856-864.

Izadi, J \& Mosleh Shirazi, A. N. (2012). The study of the economic effects of the development of industrial clusters (Case study of Golab and pesticides and medicinal plants cluster Fars), Second National Conference on Economic Development Strategies whit Focusing on Regional Planning, Faculty of Humanities, Islamic Azad University, Sanandaj, 9, and 10 June, 2012, pp. 1-7.

Jin, X, Weber, K, and Bauer, T. (2012). “Impact of clusters on exhibition destination attractiveness: Evidence from Mainland China", Tourism Management, 33, 1429-1439.

Kopahi, M., and Darban Astaneh, A. (2002). Measuring and Analyzing the Efficiency of Rural Small Industries (Case Study: Khorasan Province), Journal of Iranian Agricultural Science, Vol. 33, No. 4, pp. 661-669.

Kord, B. and Khashi, E. (2014). Identification and Prioritization of the Industrial Clustering Factors Using the Network Analysis Process (Case Study: Saravan Date Industrial Cluster), Entrepreneurship Development, Volume 7, Issue 2, pp: 247-265.

Mansori, E. and Aziz Mohamadlo, H. (2009). Cluster Development Projects (Programs and Achievements), Publisher: Public Relations and International Organization of Small Industries and Industrial Towns of Iran, pp. 1-133.

Moradi, Kh, Agahi H, Zarafshani, K., and Popzan, A.H. (2015). Qualitative Analysis of Processing Challenges in Fruit Processing Conversions in Kermanshah Province (Application of NVivo Software). Journal of rural research, Volume 6, Issue 3, pp: 483-514.

Motiei Langroudi, S.H. and Najafi Kani, A.A. (2011). Development and Industrialization of the rural (Theories, Methods and Strategies for Industrial Development), First Edition, Tehran University.

Musso, F \& Francioni, B. (2015). Agri-Food Clusters, Wine Tourism and Foreign Markets. The Role of Local Networks for SME's Internationalization, 22nd International Economic Conference - IECS 2015 “Economic Prospects in the Context of Growing Global and Regional Interdependencies", Procedia Economics and Finance 27 (2015) $334-343$.

Parausic, V., Cvijanovic, J \& Mihailovic, B. (2013). Market analysis of clusters in Serbian agribusiness, Economics of Agriculture (60) 4: 713-728. UDC: 339.56:631(497.11).

Papzan, A. H \& Delangizan, S. (2008). Greenhouse Cooperative Cluster: A New Approach to Graduates of Agricultural Colleges, First National Conference on Cooperatives and Agriculture.

Radfar, R. (2013). Basic concepts related to agricultural clusters (cluster FAQs), Ministry of Agriculture, Planning Research Institute, Agricultural Economics and Rural Development. PP: 1-15.

Roy, D. \& Thorat, A. (2008). Success in High-Value Horticultural Export Markets for Small Farmers: The Case of Mahagrapes in India. World Development 36(10): 1874-1890.

Sajasi Kheidari, H., Sadeghloo, T., and Palouj, M. (2013). Prioritizing Sustainable Livelihoods Development Strategies Using SWOT-Topsis-Fuzzy Combined Model: Case Study Khodabandeh County, Journal of rural and Development Vol. 16, No. 2, pp. 85-110.

Shakoori, A. (2011). Agricultural Development Policy in Iran Sahand Publication, Fourth Edition. 
Sharifzadegan, M. H., and Nouri, H. (2015). Characteristics of industrial clusters and its effects on regional development, Journal of Science, Vol. 5, No. 2, pp. 48-53.

Sharma, S \& Anupam, P. (2014). Agro-based cluster: A Tool for competitiveness of Indian agriculture in the ERA of globalization, Global Journal of Finance and Management. ISSN 09756477 Volume 6, Number 8 (2014), pp. 713-718. Research India Publications http://www.ripublication.com.

Straus, A., \& Corbin, J. (1998). Basic of qualitative research: techniques and procedures for developing grounded theory. 2nd ED. Sage Publications, Thousand Oaks, California.

Zohorian, M., and Rahimnia, F. (2015). Presentation of Sustainable Development Pattern of Business Cluster in Iran, Development Entrepreneurship, Volume 8, Issue 1, pp. 59-41. 